\title{
W SPRAWIE OBRAZU KULTURY MATERIALNEJ DWORÓW RYCERSKICH W ŚREDNIOWIECZU
}

SŁowa KLUCzowe: dwory rycerskie, badania archeologiczne, kultura materialna, datowanie

KEYwORDs: manors knights, archaeological research, material culture, dating

Jako archeolodzy, za relikty dworów rycerskich uznajemy - w dużym uproszczeniu - stanowiska z okresu średniowiecza, o własnej formie terenowej, wskazującej na ich pierwotnie obronny charakter, czyli różnego typu grodziska. Tym samym musimy zdać sobie sprawę z niepełnej ilości rozpoznawanych przez nas obiektów mieszkalnych, należących do bogatszej i bardziej zaradnej części rycerstwa (Kajzer 1987). Drugim ograniczeniem jest oczywiście liczba i stopień zachowania tego typu stanowisk. Wymienione ograniczenia mają charakter barier oczywistych i obiektywnych. Rodzi się zatem pytanie, na ile archeolodzy są w stanie wykorzystać tę - i tak uszczuploną - bazę danych. Jak wynika z kwerendy we wszelkiego rodzaju publikacjach archeologicznych, na terytorium średniowiecznego państwa polskiego (umownie w granicach z czasów panowania Kazimierza Wielkiego) rozpoznano w różnym stopniu około 200 grodzisk, będących pozostałościami dworów rycerskich (w wyliczeniach nie uwzględniałam obiektów państwowych i należących do duchowieństwa). Zestawienia badanych grodzisk, bez rozróżnienia przynależności społecznej właścicieli dla obecnych terenów Polski były publikowane (Kóčka-Krenz 1993; Marciniak-Kajzer 2011a). Stopień ich poznania jest bardzo różny, a jeszcze bardziej różnorodne są formy określania w publikacji stopnia zaawansowania działań badawczych. Nie zawsze czytelnik jest w stanie odgadnać, co właściwie na danym stanowisku zrobiono. Poza ,,badaniami wykopaliskowymi”, i ,,powierzchniowymi", nie wypracowaliśmy bowiem definicji innych działań terenowych. Nie do końca ścisłe są określenia typu: „,badania sondażowe”, ,inwentaryza- 
cyjne”, „zwiadowcze” czy „,inwentaryzacyjno-konserwatorskie”, a tym bardziej „badania ratownicze”, których zakres może być przecież bardzo różny. Niełatwo odpowiedzieć na pytanie, czy „,badania sondażowe” to tylko „powierzchniówka”, czy może wiercenia, a nawet jakiś niewielki wykop. Czy badania inwentaryzacyjne ograniczyły się do tzw. autopsji (które to określenie jest dla mnie zupełnie niejasne), czy może przy okazji zrobiono ,powierzchniówki” i plan sytuacyjnowysokościowy? Wątpliwość można mnożyć. $\mathrm{Z}$ tego trudno jest dokonać pewnych interpretacji i obliczeń, na ilu stanowiskach archeolodzy przeprowadzili badania wykopaliskowe (o bardzo różnym zakresie) - od jednego małego wykopu do ponad kilku arów przebadanej powierzchni. Niestety wyniki tych, jak widać znacznych, działań terenowych w literaturze fachowej zostały udostępnione w niewielkim stopniu. Nawet w Informatorze Archeologicznym nie ma notek o wszystkich wykopaliskach, natomiast innego typu badania, w tym różnie pojęte ,sondażowe”, z reguły nie są tam odnotowywane. Zaledwie około $46 \%$ badanych wykopaliskowo stanowisk zostało opracowanych, w mniej lub bardziej rozbudowanych, całościowych publikacjach - niektóre stanowiska doczekały się publikacji cząstkowych, omawiających tylko najbardziej interesujące znaleziska. Zwykle na publikację zasługiwały bogate zbiory militariów lub kafli piecowych. Niestety zdarzało się, że przy okazji ich omawiania nie podawano nawet kategorii i liczby innych odnalezionych przedmiotów.

Kłopoty z pozyskaniem wiedzy na temat badanych stanowisk nie kończą się nawet wówczas, gdy do naszych rąk trafia „całościowa publikacja” poświęcona danemu stanowisku.

O ile forma badanego siedliska i opisy poszczególnych „obiektów” (również trudne do zdefiniowania określenie) zwykle przedstawione są dość skrupulatnie, to odnalezione zabytki nazbyt często są jedynie wymieniane. Najczęściej nie wiadomo, z której części stanowiska pochodzą. Wprawdzie czasami omawiane są w ramach wykopów, ale trudno się zorientować czy znajdowały się w budynku, na dziedzińcu, a może w fosie? Inny sposób to omawianie artefaktów według warstw, w jakich zostały odnalezione, ale często bez podanej ich chronologii.

Spotkać można również zupełnie irracjonalne opracowania, gdzie po dokładnym opisie stratygrafii np. dwóch faz użytkowania badanego obiektu, następuje swoista „wyliczanka” odnalezionych zabytków, nawet bez próby przyporządkowania ich poszczególnym okresom zasiedlania stanowiska: „Materiał zabytkowy stanowią ułamki naczyń, płytek posadzkowych, kafli, gwoździe i fragmenty naczynia szklanego pochodzące z XIV-XVII wieku"”.

${ }^{1}$ Ponieważ celem tego artykułu nie jest napisanie recenzji poszczególnych publikacji, a tylko zobrazowanie pewnych zjawisk, przytaczane cytaty nie zostały zaopatrzone $\mathrm{w}$ adresy bibliograficzne. 
Dokładnym opisom wykopów i warstw, zwykle nie towarzyszy nawet próba końcowej rekonstrukcji siedliska. W innych wypadkach autorzy posiłkują się łatwymi analogiami, nie podejmując specjalnych wysiłków, aby nas przekonać, że są one uprawomocnione:

Jeśli chodzi o konstrukcję wieży, to możemy uznać, że była to najprawdopodobniej konstrukcja zrębowa. Spotkano się z nią na analogicznych gródkach, m.in. w Siedlątkowie, [...]. Za takim rozumowaniem przemawia również brak śladów po słupach, które sugerowałyby obecność konstrukcji słupowo-szkieletowej, stwierdzonej na doskonale rozpoznanym gródku w Plemiętach.

Spektakularny charakter wykopalisk na dwóch wspomnianych stanowiskach, zaważył w ogromny sposób na poglądach na temat form budynków na kopcach. W konsekwencji wielu autorów zapomina, że w średniowieczu znano, co najmniej, kilka sposobów budowania domów i nawet nie poszukuje śladów innych konstrukcji.

Powróćmy jednak do zasadniczego nurtu naszych rozważań. Zgodzimy się chyba wszyscy, że znaczną część swoich wysiłków badawczych poświęcamy badaniu kultury materialnej. Niestety, analizując sprawozdania i publikacje dochodzi się do smutnego wniosku, że archeolodzy oderwali przedmiot swoich badań od rzeczywistości. Piszą o spagu warstwy, zamiast o podłodze chałupy, która zwykle nie jest nazywana budynkiem, tylko „obiektem” lub ,jamą” o kolejnym numerze. Opisują fragmenty ceramiki, a nie garnki, dzbanki i misy, jak również ułamki kafli, ale już nie piece.

Paradoksalnie najgorzej opracowywane są znaleziska masowe, czyli ceramika naczyniowa. Jej opis to najczęściej zaledwie podana liczba zachowanych fragmentów, bez choćby próby rozpoznania formy naczyń. Nawet wstyd wspominać, ale zdarzają się przypadki, że materiał określany jako „niecharakterystyczny” wcale nie jest opracowywany. O ile w ogóle podawane są kategorie funkcjonalne naczyń, to mianem garnków nagminnie określa się wszystko, nawet wówczas, gdy pojawiają się opisy, a nawet rysunki krawędzi ewidentnie należących do dzbanów czy mis. Jeszcze gorzej wygląda sprawa datowania znalezionych ułamków ceramicznych, ale tutaj wypada tylko odesłać do znakomitych prac Jerzego Kruppégo (1980; 1993) i życzyć nam wszystkim, abyśmy jak najrzadziej napotykali w publikacjach określenia chronologiczne typu: „ceramika w najlepszym wypadku późnośredniowieczna".

Jeśli chodzi o opisy technologiczne i formalne, w zasadzie można tu przytoczyć wszystkie zarzuty, jakie pod naszym adresem wysunął swego czasu Andrzej Buko (1979; 1988), od lat postulujący bardziej naukowe podejście do 
tak prozaicznej kategorii zabytków, jakimi są kawałki skorup. Ich kompletne lekceważenie do dziś czasami jeszcze owocuje nieco ,prahistorycznym” zwyczajem sporządzania ,inwentarza zabytków wydzielonych”. Znajdujemy w nim właściwie wszystko, oprócz fragmentów ceramiki i kości zwierzęcych. Trudno doprawdy się domyślać, skąd przekonanie o nikłych walorach poznawczych tych właśnie kategorii znalezisk. W niewielu opracowaniach autorzy powołują się na analizy osteologiczne, choć nie są one zbyt drogie, a przecież wiadomości, czy w konsumpcji preferowano zwierzęta hodowlane (i jakie?) czy łowne, w znacznym stopniu mogą wpłynąć na nasze postrzeganie nie tylko upodobań kulinarnych rycerstwa, ale także na poziom naszej wiedzy dotyczącej sposobów życia i systemów gospodarczych.

W wielu publikacjach w pełni doceniane są natomiast zabytki metalowe. Nazbyt często jednak troska o ich opracowanie kończy się na bardzo dokładnym wymienieniu każdej, najdrobniejszej nawet bryłki żelaza. Niestety w wykazach zbyt wiele jest przedmiotów określonych jako „nieokreślone”. Brak pieniędzy na zdjęcia rentgenowskie i konserwację takie praktyki usprawiedliwia jedynie częściowo. Może więc należy przytoczyć poglądy, coraz rzadziej już cytowanej - i chyba dzisiaj niesłusznie niedocenianej badaczki średniowiecza - Janiny Kamińskiej, która o przedmiotach „niezidentyfikowanych” pisała tak:

[...] rzadko się je rysuje [...]. Dlatego też w tabelach wprowadzono rubrykę przedmiotów nie rozpoznanych, beż nazwy, a w materiale rysunkowym potraktowano je ze szczególną uwagą licząc się z tym, iż wywołują zainteresowanie wśród znawców kowalstwa wiejskiego.

W tym przypadku, dokładne wyrysowanie całego materiału zabytkowego zaowocowało późniejszym odkryciem przez bronioznawców fragmentów kuszy z Siedlątkowa, podczas gdy Janina Kamińska (1968: 35), zamieściła jej fragment na tablicy zatytułowanej „sprzęt kowalski”.

Najbardziej nierównomiernie opracowaną kategorią zabytków są, jak się wydaje, kafle piecowe. Jeżeli odnaleziony ich zbiór jest bogaty i interesujący, powstają samodzielne opracowania i próby rekonstrukcji pieców. I tu również nie mogę oprzeć się wrażeniu, że czasami działania te prowadzi się w oderwaniu od rekonstrukcji całego domostwa, z którego pochodziły. Jeżeli natomiast zbiór kafli nie jest zbyt bogaty, przekazywane informacje należy określić jako, co najmniej, skromne. Najbardziej rażąca jest tutaj dowolność określeń używanych do opisu poszczególnych typów kafli. Bo o ile nawet łatwo wyobrazić sobie kafel „doniczkowaty”, to już z formą „rynienkowatą” można mieć pewne trudności. Rekonstrukcja formy pieca, na podstawie odnalezionych fragmentów kafli, nie 
jest z pewnością łatwa. Czasami jednak brakuje choćby konstatacji, że dany piec zbudowany był z kafli naczyniowych lub płytowych, i podania, choćby w przybliżeniu, ich kolorystyki. To, jak sądzę, nie przerasta już możliwości nawet początkujących badaczy.

Nie lepiej przedstawia się sytuacja w przypadku nazewnictwa różnego typu narzędzi. Aż nazbyt często daje o sobie znać uszczuplenie programów uniwersyteckich i wyrzucenie z nich etnografii, czy nowocześniej nazywanej etnologii. Gdyby ich nie usunięto, może rozpoznanie zgrzebła czy motyki przychodziłoby badaczom łatwiej.

Z najwyższą uwagą wszyscy archeolodzy traktują natomiast wszelkie znaleziska z zakresu militariów. Opisywane są one pieczołowicie i starannie, ale ta właśnie kategoria zabytków wprowadza czasami wiele zamieszania w próby datowania badanego stanowiska. Militaria zwykle uważane są za tak zwane „dobre datowniki” i tu oczywiście należy się zgodzić, o ile datują same siebie. Natomiast całkowity sprzeciw budzi sytuacja, gdy, dla przykładu, jedna znaleziona ostroga przesuwa (bywa, że nieraz o wiek) datowanie ustalone na podstawie setek fragmentów naczyń i kafli piecowych. Zagadnienie „dobrych datowników", do których oprócz militariów zalicza się między innymi monety, było już przecież podnoszone w literaturze przedmiotu, ale jak się można przekonać, nie doczekało się szerszej refleksji wśród badaczy (Kajzer 1997; Tokarski 1997). Niestety, w dalszym ciagu pojawiają się takie stwierdzenia:

Ceramika omawianej grupy posiada zatem wszystkie cechy typowe dla naczyń średniowiecznych, lecz dokładne datowanie jej utrudnia brak zabytków o dobrze ustalonej chronologii, występującej razem z nią w tych samych skupiskach.

Z zagadnieniem ,dobrych datowników” ściśle wiąże się kwestia przywiązania archeologów do różnego rodzaju typologii. O ile w przypadku uzbrojenia czy oporządzenia jeździeckiego większość z nas skrupulatnie sięga do klasyfikacji zaproponowanych przez znawców broni, o tyle w przypadku innych kategorii znalezisk boleśnie daje się odczuć nieznajomość już opracowanych i publikowanych typologii. Owocuje to, zwykle niestety nieudolnymi, próbami budowania własnych ciagów typologicznych dla znalezisk z jednego stanowiska. I tu, jak się wydaje, najgorzej wygląda sytuacja z kaflami piecowymi. Pomimo że znakomita książka Marii Dąbrowskiej (1987) Kafle i piece kaflowe w Polsce do końca XVIII wieku ukazała się już piętnaście lat temu, a większość egzemplarzy ukradziono ze znanych mi bibliotek, zawarte tam typologie i klasyfikacje nie w pełni jeszcze ugruntowały się w świadomości wszystkich badaczy. 
Podsumowując przedstawione powyżej spostrzeżenia, które (co zauważyłam z przykrością) w znacznej części odnieść mogę i do własnych opracowań, stwierdzić trzeba, że obraz kultury materialnej dworów rycerskich w średniowieczu na podstawie badań archeologicznych, przypomina raczej rozrzucone puzzle, a nie skompletowany obrazek. Teoretycznie dysponujemy wszystkimi elementami układanki, jednak niewielu badaczy podejmuje trud dopasowania ich do siebie, w celu stworzenia spójnej całości. Doświadczony archeolog, oglądając te fragmenty, jest być może w stanie wyobrazić sobie całość, jednak naszym zadaniem jest również udostępnianie wyników badań przedstawicielom innych nauk historycznych. Tymczasem pełne zrozumienie naszych publikacji przez „nie archeologa" jest utrudnione z przynajmniej dwóch powodów. Po pierwsze - pisane są swoistym żargonem, nie zawsze dobrze rozumianym przez przedstawicieli innych dyscyplin. Po drugie - brakuje w nich zwykle podsumowania, w którym przedstawiona byłaby próba rekonstrukcji badanego obiektu. W podsumowaniu takim należałoby zrezygnować $\mathrm{z}$ archeologicznego slangu i opisać budynek, a nie obiekt czy jamę. Warto nawet wówczas podawać informacje wynikające z braku danych, na przykład, że w badanym materiale ruchomym nie występuje szkło okienne, a w przypadku braku kafli, zaznaczyć, że mieszkańcy nie korzystali z dobrodziejstw ogrzewania piecowego. Dobrze byłoby również zastapić statystykę fragmentów ceramiki naczyniowej opisem używanych przez mieszkańców, zarówno w kuchni, jak i przy stole, garnków, misek czy kubków. Wydaje się, że taki zabieg nie byłby zbyt trudny i pracochłonny, mógłby natomiast przynieść znaczące korzyści.

Chyba wszyscy zdajemy sobie sprawę, że w wyniku wykopalisk odkrywamy zaledwie część przedmiotów, które towarzyszyły człowiekowi w badanym przez nas miejscu. Wiele $\mathrm{z}$ nich, w tym zdecydowana większość wykonana z surowców organicznych, uległa zniszczeniu i tylko w wyjątkowych okolicznościach trafiają one do naszych rąk. Powszechnie doceniana jest więc konieczność korzystania ze źródeł pisanych czy ikonograficznych w celu odtworzenia całości kultury materialnej. Tutaj niezbędna jest współpraca z mediewistami i historykami sztuki. Niestety, jak sugerowałam to wcześniej, nie jesteśmy zbyt łatwymi, a co za tym idzie atrakcyjnymi, partnerami w tych badaniach. Sprawa jest tym trudniejsza, że wśród historyków zajmowanie się kulturą materialną nie jest zbyt popularne (Marciniak-Kajzer 2011b: 122). Nawet laik zauważy, że w publikacjach mediewistów występują często postulaty zintensyfikowania badań nad historią społeczną. Wydaje się jednak, że obraz społeczeństwa średniowiecznego nie będzie pełny, jeśli w jego omówieniach nie zaistnieją przedmioty, bez których społeczeństwo to nie mogło przecież funkcjonować i które w wielu 
wypadkach warunkowały jego rozwój. Nie uwzględniając roli przedmiotów, tracimy ważną przesłankę, pomagającą być może wyjaśnić pewne zagadnienia nie tylko gospodarcze, ale i społeczne, a nawet polityczne. Dla przykładu: czy można w pełni wyjaśnić funkcjonowanie różnego rodzaju wspólnot terytorialnych, jeśli nie znamy wszystkich przyczyn, dla których taki właśnie a nie inny sposób użytkowania ziemi był konieczny? Przecież zarówno wielkość areałów, sposoby uprawy, wydajność i możliwość wyżywienia ściśle określonej grupy ludzi, były w sposób zasadniczy związane z wykorzystywaniem określonych narzędzi rolnych. W rozważaniach nad zmiennością układów społecznych i gospodarczych historycy omawiają cały wachlarz przyczyn, poświęcając jednak bardzo mało uwagi przedmiotom, bez udoskonalania których część tych zmian mogłaby w ogóle nie zajść. Takie podejście do sprawy jest zupełnie zrozumiałe - historycy, korzystając ze źródeł pisanych, otrzymują zbyt mało przesłanek do właściwej oceny znaczenia elementów kultury materialnej.

I tak powróciliśmy do roli archeologa, który po pierwsze, wiedzę na temat przedmiotów towarzyszących człowiekowi powinien zdobyć, po drugie jednak ma obowiązek ją udostępnić i spopularyzować, a z tym, jak już wiadomo, środowisko nasze ma niejakie kłopoty.

Nie znaczy to oczywiście, że nie ma wśród archeologów i historyków osób, które rozumieją i doceniają potrzebę tworzenia „całych obrazków”, a nie tylko zabawiania się poszczególnymi klockami. Każdy rodzaj stanowiska ma swoją specyfikę wymagającą nie tylko zastosowania odmiennych metod eksploracji i dokumentacji. W odmienny sposób również dochodzić trzeba do końcowych rekonstrukcji, dysponując innym zestawem pytań. Jeśli chodzi o badanie grodzisk pochodzących z okresu średniowiecza, taki zestaw pytań powstał już prawie pół wieku temu, ale jak się wydaje, został gruntownie zapomniany. Mam tu na myśli model badawczy opracowany przez Janinę Kamińską. Kilka lat temu starałam się go przypomnieć (Marciniak-Kajzer 2007) - pomimo to przytoczę tu jeszcze raz najważniejsze jego aspekty.

Większość badaczy gródków stożkowatych nawiązuje do jednych z najwcześniejszych i najbardziej spektakularnych badań tego typu obiektu, czyli do wykopalisk Janiny Kamińskiej w Siedlątkowie. Szkoda jednak, że tak często poprzestajemy na prostych analogiach, zamiast wziąć przykład z końcowego opracowania wyników badań tego stanowiska, które dziś jeszcze można uznać za wzorcowe (Kamińska 1968:35). W publikacji tej znajdziemy wszystkie wiadomości wstępne, które archeolog powinien zgromadzić przed przystapieniem do badań terenowych, czyli: historię miejscowości i jej właścicieli, analizę geomorfologiczną, uwagi o jakości ziemi i zalesieniu, a także bogactwach naturalnych 
i ich eksploatacji w przeszłości. Opis samych wykopalisk poprzedza omówienie wyników poszukiwań gospodarczej zabudowy towarzyszącej i najbliższej wsi. Natomiast plan opracowania archeologicznego wygląda następująco:

1) opis prac, stosowanych metod, układu warstw kulturowych

2) statystyka uzyskanych materiałów

3) opis wieży mieszkalnej i jej urządzeń wewnętrznych

4) analiza naczyń glinianych

5) próba ustalenia chronologii

6) zakończenie, omawiające znaczenie odkryć w Siedlątkowie i wiążące historię gródka z nurtem spraw gospodarczych, społecznych i politycznych Polski XIV w., mających swe odbicie w dziejach wsi sieradzkiej.

7) trzy artykuły specjalistyczne: omawiające hełm i fragmenty zbroi z Siedlątkowa, kuźnię w Siedlątkowie i opracowanie materiałów osteologicznych.

Dodać warto, że autorka dokonała między innymi próby rekonstrukcji pieca, przeanalizowała rozmieszczenie naczyń w poszczególnych poziomach stratygraficznych, identyfikowanych z poszczególnymi pomieszczeniami dworu. To pomogło $\mathrm{w}$ interpretacji funkcji mieszkalnych i gospodarczych rekonstruowanych wnętrz. Na poparcie swych analiz J. Kamińska przytoczyła również liczne analogie $\mathrm{z}$ innych stanowisk.

Nie będzie łatwo stworzyć nowy, lepszy model takiego opracowania. Ale płynie z tego także jeden optymistyczny wniosek: wzór już mamy, należy tylko go stosować.

prof. dr hab. Anna Marciniak-Kajzer

Uniwersytet Łódzki

Wydział Filozoficzno-Historyczny

Instytut Archeologii

ul. Uniwersytecka 3

90-137 Łódź

\section{BibLIOGRAFIA}

Buko A. (1979), Problemy analizy opisowej wyrobów garncarskich zachowanych fragmantarycznie, „Kwartalnik Historii Kultury Materialnej”, R. 27, nr 2, s. 187-207.

Buko A. (1988), O niektórych aspektach opisu wyrobów garncarskich, „Archeologia Polski”, t. 33, z. 1, s. 210-219. 
Dąbrowska M. (1987), Kafle i piece kaflowe w Polsce do końca XVIII wieku, Warszawa.

Kajzer L. (1987), Czy tzw. gródki stożkowate były fundacjami ,średniego rycerstwa”?, [w:] Średniowieczne siedziby rycerskie w na tle badań podobnych obiektów na ziemiach polskich, red. A. Kola, Toruń, s. 105-126.

Kajzer L. (1997, Wqsko czy szeroko”. Uwagi o datowaniu stanowisk archeologicznych z czasów historycznych, „Archaeologia Historica Polona”, t. 6, 1997, s. 23-43.

Kamińska J. (1968), Siedlatków, obronna siedziba rycerska z XIV wieku, „Prace i Materiały Muzeum Archeologicznego i Etnograficznego w Łodzi”, seria archeologiczna, nr 15, s. 15-87.

Koczerska M. (2001), Nauki pomocnicze historii średniowiecznej w Polsce - stan $i$ perspektywy badawcze, [w:] Pytania o średniowiecze. Potrzeby $i$ perspektywy badawcze polskiej mediewistyki, red. W. Fałkowski, Warszawa, s. 167-185.

Kóčka--Krenz H. (1993),From the Research into Medieval Wooden Tower Houses in the Polish Territories, [w:] The Study of Medieval Archaeology. European Symposium for Teachers of Medieval Archaeology, Lund 11-15 June 1990, Stockholm, s. 293-299.

Kruppé J. (1980), Garncarstwo późnośredniowieczne w Polsce, Wrocław

Kruppé J. (1993), Garncarstwo późnośredniowieczne w Polsce. Stan badań archeologicznych, „Prace i Materiały Muzeum Archeologicznego i Etnograficznego w Łodzi”, seria archeologiczna, nr 36, s. 151-157.

Marciniak-Kajzer A. (2007), Recepta wciqż aktualna, czyli Janiny Kamińskiej poglady na metodyke badań średniowiecznych dworów, [w:] Od pradziejów do wspótczesności. Archeologiczne wędrówki. Studia dedykowane Pani Profesor Marii Magdalenie Blombergowej, red. M. Głosek, J. Maik, Łódź 2007, s. 96-100.

Marciniak-Kajzer A. (2011a), Średniowieczny dwór rycerski w Polsce. Wizerunek archeologiczny, Łódź.

Marciniak-Kajzer A. (2011b), Badania nad kultura materialna średniowiecznego dworu rycerskiego $w$ optyce archeologa, [w:] Polska i Europa $w$ średniowieczu. Przemiany strukturalne. Podmioty i przedmioty $w$ badaniach historycznych, red. M. Adamczewski, Warszawa 2011, s. 115-123.

Tokarski W. (1997), Średniowieczne militaria jako wyznaczniki chronologii, „Archaeologia Historica Polona”, t. 6, 1997, s. 55-68.

Wyrozumski J. (1993), Potrzeby i perspektywy badań nad społeczeństwem Polski średniowiecznej, „Studia Historyczne”, 41, 1998, z. 3, s. 317-324.

Wyrozumski J. (2001), Badania nad społeczeństwem średniowiecznej Polski, [w:] Pytania o średniowiecze. Potrzeby i perspektywy badawcze polskiej mediewistyki, red. W. Fałkowski, Warszawa. 
SuMMARY

\section{THE IMAGE OF THE MATERIAL CULTURE OF MEDIEVAL KNIGHT’S MANORS}

Most archaeological sites, which were considered remains of medieval knight's manor have readable (separated) terrain form. Most frequently they were situated on artificial mounds, placed in boggy areas, often in valleys of small rivers. As can be seen from the query in all kinds of archaeological publications, on the territory of medieval Polish state (conventionally within the reign of Casimir the Great) about 200 mansions that are relics of knight's abodes ware investigated in varying degrees. The degree of their knowledge is very different. Only about $46 \%$ sites being excavated were elaborated and the results were published with different accuracy. Their scientific level is unfortunately very diverse. While the form of the seats are usually described in a very detailed way, the artifacts found during excavations are mostly only mentioned. Most often we do not know from which part of the site they come from. Although they are sometimes discussed in the framework of the excavation, but it is hard to know if they were in the building or in the courtyard, and perhaps in the moat? Paradoxically, most numerous finds - potsherds - are the least described. They are only enumerated, without even trying to identify forms (vase, pot, jag...). Also, in the case of metal objects, they description very often ends up on the development of an accurate list of the every, even the slightest, iron nuggets. Unfortunately, there are too many lists of objects referred to as „undefined”. With the greatest care archaeologists treat all and any findings in the field of armament, but this is the category of monuments which sometimes introduces a lot of confusion in trying the dating of the settlement. The armament usually is considered to be the so-called „a good dating device” and of course, it is true, provided that it date back itself. Sometimes the total opposition raises in a situation where, for example, dating of one found spur, is considered to be more important than dating established on the basis of hundreds found fragments of vessels and stove tiles.

Therefore the necessity to use written and iconographic sources in order to reconstruct the whole material culture is widely appreciated. Here it is necessary to work with medievalist and art historians. It is not a simple matter because dealing with material culture is not very popular among the historians. In the final part of the article the development of a model of conical settlement excavations in Siedlatców published by Janina Kamińska in 1968 is discussed. 